\title{
KINERJA KEUANGAN PERBANKAN DI INDONESIA TAHUN 2015 \\ DILIHAT DARI SUDUT RASIO LIKUIDITAS DAN RASIO SOLVABILITAS SEBAGAI SUMBER BELAJAR PADA MATA KULIAH ANALISA LAPORAN \\ KEUANGAN
}

\author{
Oleh: Diana Widhi Rachmawati ${ }^{1}$, Satria Andika, dan Hesti \\ (UNIVERSITAS PGRI PALEMBANG) \\ 1) dianawidhi72@yahoo.com
}

\begin{abstract}
Abstrak
Bank merupakan lembaga keuangan yang menghimpun dana masyarakat dan menyalurkannya kepada pihak yang membutuhkan dan mempunyai peranan yang sangat penting dalam system perekonomian yang semakin bertumbuh seiring dengan semakin bertumbuhnya kebutuhan masyarakat. Lembaga perbankan juga berperan sebagai Agen Pembangunan (Agent of Development) dalam pembangunan nasional, dimana bank menyalurkan dananya kepada masyarakat dalam bentuk kredit, guna meningkatkan kemampuan mobilitas dana, serta menciptakan iklim yang lebih baikbagi dunia usaha. Analisis lapora nkeuangan (financial statement analysis) adalah aplikasi dari alat dan teknik analisis untuk laporan keuangan bertujuan umum dan data-data yang berkaitan untuk menghasilkan estimasi dan kesimpulan yang bermanfaat dalaman alisis bisnis. Analisis Laporan Keuangan yang digunakan dalam penelitian ini menggunakan Metode Analisa Ratio yang terdiri dari : Ratio Liquiditas dan Ratio Solvabilitas. Tujuan umumnya adalah untuk memberikan informasi perkembangan kinerja keuangan perbankan di Indonesia tahun 2015 dilihat dari rasio likuiditas dan solvabilitas.Tujuan khusus sebagai salah satu pembahasan dalam mata kuliah Analisis Laporan Keuangan. Sampel dari penelitian ini adalah :Bank Mandiri, Bank BCA, Bank BRI, Bank BNI, dan Bank CimbNiaga. Hasil akhir yang diperoleh dari penelitian adalah hasil analisis Likuid dan Solvabel, sebagai bank besar yang berkembang sangat pesat, mereka memiliki asset dan modal sendiri yang masih kuat sehingga dapat membiayai pelaksanaan operasional perbankan di perusahaan.
\end{abstract}

Kata Kunci: Kinerja Keuangan Perbankan

THE FINANCIAL PERFORMANCE OF BANKING IN INDONESIA ON 2015 FROM LIQUIDITY RATIO AND SOLVABILITIES RATIO AS A LEARNING RESOURCE FOR FINANCIAL REPORT ANALYSIS SUBJECT

\footnotetext{
Abstract

The bank is one of economic company which collecting people's money and give it to the parties in need and have a very important role in economic system that always increase following peoples neeeded. Banking institution also play in role as an agent of
} 
development in national development where the bank giving the fund to the community in the form of credit to increase the ability of fund mobility and also make a better climate in the business worl. The financial statement analysis is the aplication from tools and techniques for financial report for a general and related data to produce an estimated and the conclution that very useful in business analysis. The analysis of financial report in this research is Ratio Analysis methode which contain : Liquidity ratio and Solvability Ratio. The general purpose is to give an information about banking financial performance developent in Indonesia in 2015 from liquidity ratio and solvability ratio. The specific purpose is one of courses topic financial report analysis. The sample of this research are: Mandiri Bank, BRI Bank, BCA Bank, BRI Bank, BNI Bank, and CIMB Niaga. The final result from this research is the final of Likuid and Solvabel, is The big bank that growing rapidly, they have an asset and their own capital so they can pay their own finance banking operation implementation.

Keyword: Banking Financial Performance

\section{PENDAHULUAN}

Perkembangan Ekonomi yang semakin pesat saat ini memerlukan berbagai unsur penunjang dibidang perekonomian dimana salah satu di antaranya aadalah bank. Bank merupakan lembaga keuangan yang menghimpun dana masyarakat dan menyalurkannya kepada pihak yang membutuhkan dan mempunyai peranan yang sangat penting dalam system perekonomian yang semakin bertumbuh seiring dengan semakin bertumbuhnya kebutuhan masyarakat. Lembaga perbankan juga berperan sebagai Agen Pembangunan (Agent of Development) dalam pembangunan nasional, dimana bank menyalurkan dananya kepada masyarakat dalam bentuk kredit, guna meningkatkan kemampuan mobilitas dana, serta menciptakan iklim yang lebih baik bagi dunia usaha.
Dunia perbankan telah mengalami banyak perubahan dari tahun ke tahun, antara lain semakin meningkatnya kebutuhan masyarakat dengan jasa perbankan, baik karena adanya rasa waspada terhadap masa yang akan datang sehingga membuat masyarakat ingin menyimpan sebagian dananya, maupun untuk kelancaran usaha mereka. Bertambahnya kebutuhan tersebut, maka perbankan juga harus meningkatkan pula tingkat pelayanan mereka kepada masyarakat, agar mampu melindungi secara baik dana yang dititipkan masyarakat kepadanya serta mampu menyalurkan dana masyarakat tersebut bagi terciptanya sasaran pembangunan. Hal ini ditandai dengan adanya fasilitas-fasilitas yang memudahkan dalam bentuk simpanan maupun pinjaman, serta kemudahan 
dalam sirkulasi uang dari satu tempat ke tempat lain yang dilayani oleh bank.

Keberhasilan penghimpunan dana-dana di masyarakat dapat dicapai jika adanya kepercayaan masyarakat terhadap pecapaian keberhasilan yang berhasil diwujudkan oleh dunia perbankan, dimana akan berdampak juga dengan meningkatnya tingkat investasi yang ditanamkan oleh para investor di dunia perbankan dan semuanya diinformasikan langsung oleh pihak perbankan kepada masyarakat luas.

Bagaimana kinerja keuangan perbankan di Indonesia tahun 2015 dilihat dari rasio likuiditas dan rasio solvabilitas?

Kasmir (2013), Dunia bisnis merupakan dunia yang paling ramai dibicarakan diberbagai forum, baik yang bersifat nasional maupun internasional. Ramainya pembicaraan masalah ini disebabkan, salah satu tolok ukur kemajuan suatu negara adalah dari kemajuan ekonominya dan tulang punggung dari kemajuan ekonomi adalah dunia bisnis. Masalah pokok dan paling sering dihadapi oleh setiap perusahaan yang bergerak dibidang usaha apapun selalu tidak terlepas dari kebutuhan akan dana (modal ) untuk membiayai usahanya. Simorangkir (1982), Bank umum adalah bank yang dalam usahanya mnegumpulkan dana terutama menerima simpanan dalam bentuk tabungan dan di dalam usahanya bank umum memberikan kredit berjangka pendek.

Budisantoso (2006), Bank Konvensional adalah bank yang aktivitasnya baik penghipunan dana maupun dalam rangka penyaluran dana, memberikan dan mengenakan imbalanberupa bunga atau berupa sejumlah imbalandalam persentasi tertentu yang biasanya ditetapkan per tahun.

Harahap (2009), Laporan Keuangan merupakan media informasi yang merangkum semua aktivitasbagi manajemen,investor, bank, pemerintah dan masyarakat umum. Salah satu tugas penting yang dilakukan oleh manajemen atau investor setelah akhir tahun adalah menganalisis laporan keuangan perusahaandengan tujuan menggali informasi yang lebih luas dan mendalam dari laporan keuangan.

Wild (2005), Analisis Laporan Keuangan adalah aplikasi dari tehnik dan analiss untuk laporan keuangan bertujuan umum dan data-data yang 
berkaitan untuk mengahasilkan dan kesimpulan yang bermanfaat.

Munawir (2004), Ada dua metode analisis yang digunakan oleh setiap penganalisa laporan keuangan, yaitu :

$$
\begin{aligned}
& \text { 1. Analisis Horizontal yaitu } \\
& \text { analisis dengan mengadakan } \\
& \text { perbandingan laporan } \\
& \text { keuangan untuk beberapa } \\
& \text { periode atau beberapa periode } \\
& \text { atau beberapa saat, sehingga } \\
& \text { akan diketahui } \\
& \text { perkembangannya. }
\end{aligned}
$$

2. Analisis Vertikal yaitu analisa yang hanya meliputi satu periode atau satu saat saja., dengan memperbandingkan antara pos yang satu dengan pos yang laindalam laporan keuangan.

Jumingan (2006), Kinerja merupakan gambaran prestasi yang dicapai perusahaan dalam kegiatan operasionalnya baik menyangkut aspek keuangan, aspek pemasaran, aspek penghimpunan dana dan penyaluran dana, aspek teknologi, maupun aspek sumber daya manusia.

Mahmud (2003), Ukuran kinerja Keuangan meliputi rasio-rasio berikut : a) Rasio Likuiditas mengukur kemampuan perusahaan untuk memenuhi kewajiban jangka pendeknya atau kemampuan perusahaan untuk memenuhi kewajiban keuangan pada saat ditagih.

1. Rasio Lancar yaitu kemampuan untuk membayar kewajiban lancar dengan aktiva lancar yang tersedia.

2. Rasio Kas adalah kemampuan membayar kewajiban yang harus segera dipenuhi dengan kas yang tersedia dalam perusahaan

3. Rasio Cepat adalah kemampuan untuk membayar kewajiban yang harus segera dipenuhi dengan aktiva lancar yang lebih likuid.

4. Modal Kerja untuk Total Harta adalah likuiditas dari total aktiva dan posisi kerja netto

b) Rasio Solvabilitas mengukur sejauh mana kemampuan perusahaan memenuhi kewajiban-kewajiban jangka panjangnya

1. Total Hutang untuk Total Rasio Equitas adalah bagian dari setiap rupiah modal sendiri yang dijadikan jaminan untuk keseluruhan hutang 
2. Hutang Jangka Panjang untuk Rasio Equitas adalah bagian dari setiap rupiah modal sendiri yang dijadikan jaminan untuk hutang jangka panjang

3. Total Hutang untuk Total Rasio Harta adalah beberapa bagian dari keseluruhan kebutuhan dana yang dibelanjai dengan hutang atau beberapa bagian dari aktiva yang digunakan untuk menjamin hutang

Penelitian ini dilakukan oleh penulis dengan tujuan

1. Tujuan Umum

Untuk memberikan informasi perkembangan kinerja keuangan perbankan di Indonesia tahun 2015 dilihat dari rasio likuiditas dan solvabilitas.

2. Tujuan Khusus

Sebagai salah satu pembahasan dalam mata kuliah Analisis Laporan Keuangan yaitu Analisa Rasio.

Penelitian ini diharapkan dapat memberikan kontribusi:

a) Dunia Perbankan, dapat mengeetahui bagaimana pencapaian kinerja yang telah dicapai oleh perbankan berikut dapat memperbaiki kekurangan atau penurunan yang terjadi di perbankan tersebut

b) Investor, dapat menaikkan prosentage para investor ke dunia perbankan

c) Pemerintah, dapat menggiatkan dunia usaha dan meningkatkan kepercayaan dibidang perekonomian

d) Dunia Pendidikan, dapat memberikan informasi dan sebagai sumber belajar pada mata kuliah Analisis Laporan Keuangan

Penelitian ini mengambil pokok permasalahan tentang kinerja keuangan perbankan di Indonesia tahun 2015 dilihat dari rasio likuiditas dan rasio solvabilitas.

Untuk menjawab pokok permasalahan kinerja keuangan perbankan di Indonesia tahun 2015 dilihat dari rasio likuiditas dan rasio solvabilitas, digunakan analisa rasio keuangan yang berpatokan pada Laporan Tahunan dalam hal ini Bank Mandiri, Bank BCA, Bank BRI, Bank BNI dan Bank CimbNiaga, yang meliputi neraca laporan laba/rugi 
dengan menggunakan kedua analisa rasio likuiditas dan rasio solvabilitas.

\section{PROSEDUR PENELITIAN}

Variabel adalah segala sesutu yang berbentuk apa saja yang di tetapkan oleh peneliti untuk dipelajari sehingga di peroleh informasi tentang hal tersebut, kemudian ditarik kesimpulannya. Variabel itu sebagai atribut seseorang atau objek yang mempunyai "variasi " antara satu orang dengan yang lain atau objek lain. (Sugiyono, 2012 : 60).

Sekali lagi, variabel variabel adalah objek penelitian, atau apa yang menjadi titik perhatian suatu penelitian.( Arikunto, 2010:161)

Berdasarkan pendapat di atas maka variabel dalam penelitian ini adalah:

(X) variabel terikat : Hasil Kinerja Keuangan Perbankan di Indonesia tahun 2015. Jika Dilihat Dari Sudut Ratio Likuiditas dan Solvabilitas.

Berdasarkan variabel diatas, dapat didefinisikan dalam penelitian ini adalah : Hasil Kinerja Kinerja Keuangan Perbankan di Indonesia tahun
2015. Jika Dilihat Dari Sudut Ratio Likuiditas dan Solvabilitas.

Rasio Likuiditas adalah pengukuran atas pencapaian perbankan dalam kemampuannya dalam membayar hutang jangka pendek

Rasio Solvabilitas adalah pengukuran atas pencapaian perbankan dalam kemampuannya dalam membayar hutang jangka panjang

Populasi adalah wilayah generalisasi yang terdiri atas : obyek / subyek yang mempunyai kualitas dan karakteristik tertentu yang ditetapkan oleh peneliti untuk dipelajari dan kemudian ditarik kesimpulannya ( Sugiyono 2012:117). Maka yang menjadi populasi dalam penelitian ini untuk subjek adalah peneliti dan objeknya yaitu Perbankan di Indonesia

Sampel adalah bagian dari jumlah dan karakteristik yang dimiliki oleh populasi tersebut (Sugiyono 2012:118). Sehubung dengan populasi dalam penelitian ini sedikit maka penelitian ini menggunakan penelitian populasi, sehingga yang menjadi sampel merupakan keseluruhan populasi.

Populasi dalam penelitian ini adalah perbankan di Indonesia dan Sampel dari penelitian inia dalah :

a. Bank Mandiri 


\section{b. Bank BCA \\ c. Bank BRI \\ d. Bank BNI \\ e. Bank CimbNiaga}

Dalam penelitian ini peneliti menggunakan metode penelitian kuantitatif, metode penelitian kuantitatif adalah sebagai metode penelitian yang berlandaskan pada filsafat positivisme, digunakan untuk meneliti pada populasi atau sampel tertentu, tekhnik pengambilan sampel pada umumnya dilakukan secara random, pengumpilan data mengguanakan instrumen penelitian, analisis data bersifat kuantitatif/ statistik dengan tujuan untuk menguji hipotesis yang telah ditetapkan. ( Sugiyono 2012:14 )

Metode penelitian adalah cara penelitian ilmiah untuk mendapatkan data yang valid dengan tujuan dapat ditemukan, dikembangkan, dan dibuktikan, suatu pengetahuan tertentu sehingga pada gilirannya dapat digunakan untuk memahami, memecahkan dan mengantisipasi masalah dalam bidang pendidikan

Dalam metode penelitian ini peneliti menggunakan metode eksperimen dimana metode eksperimen bermanfaat untuk menentukan mengapa suatu kondisi atau peristiwa terjadi. Metode eksperimen ini adalah suatu metode penelitian untuk mengadakan kegiatan percobaan guna mendapatkan suatu hasil.

Dengan metode eksperimen ini peneliti sengaja membangkitkan timbulnya suatu kejadian atau keadaan, kemudian diteliti bagaimana akibatnya. Dengan kata lain eksperimen adalah suatu cara untuk mencari hubungan sebab akibat, eksperimen selalu dilakukan untuk melihat akibat suatu perlakuan ( Arikunto, 2010:9)

Hal ini berarti, bahwa eksperimen merupakan percobaan untuk meneliti suatu peristiwa atau gejala yang muncul pada kondisi tertentu dan pada setiap gejala muncul diamati dan dikontrol secermat mungkin. Sehingga dapat diketahui sebab akibat munculnya gejala tersebut.

Pada penelitian ini peneliti mengambil sampel perusahaan perbankan sebagai eksperimen untuk mengetahui kinerja keuangan Perbankan di Indonesia jika dilihat dari rasio likuiditas dan solvabilitas.

Teknik pengumpulan data merupakan langkah yang paling strategis dalam penelitian, karena tujuan utama dari penelitian adalah 
mendapatkan data, tanpa mengetahui tehnik pengumpulan data, maka peneliti tidak akan mendapatkan data memenuhi standar data yang ditetapkan.(Sugiyono, 2012: 308) .

Untuk mendapatkan data yang akurat maka peneliti mengumpulkan data dengan menggunakan metode :

Dokumentasi adalah mencari data mengenai hal - hal atau variabel yang berupa catatan, transkrip, buku buku, surat kabar, majalah, notulen rapat, legger, agenda, dan sebagainya.( Arikunto, 2010:274). Teknik dokumentasi dalam penelitian ini adalah untuk memperoleh data tentang jumlah siswa dan data mengenai sekolah.

Menurut Nasution (dalam Sugiyono 2012:310) menyatakan bahwa observasi adalah dasar semua ilmu pengetahuan. Para ilmuan hanya dapat bekerja berdasarkan data, yaitu fakta mengenai dunia kenyataan yang diperoleh melalui observasi. Observasi dalam penelitian ini memuat tiga aktivitas ( indikator) yaitu aktivitas visual, aktivitas lisan, aktivitas mental dan tiap - tiap indikator memuat tiga descriptor.

Teknik analis data adalah teknik yang di gunakan untuk mengola data yang telah dikumpulkan dan di klasifikasikan sesuai dengan tujuan penelitian. Analisis adalah mampu memahami pokok masalah secara mendalam dan membandingkan data dan informasi

\section{HASIL PENELITIAN DAN PEMBAHASAN}

\section{Hasil Penelitian}

\section{BANK BRI}

\section{Likuidity Ratio}

\section{Current Ratio}

$$
\begin{aligned}
& =\frac{\text { Activa Lancar }}{\text { Hutang Lancar }} \times 100 \% \\
& =\frac{11.801 .097}{12.262 .242} \times 100 \% \\
& =0,96
\end{aligned}
$$

\section{Cash Ratio}

$$
\begin{aligned}
& =\frac{\text { Kas }+ \text { Efek }}{\text { Hutang Lancar }} \times 100 \% \\
& =\frac{21.696 .829+16.918 .059}{12.262 .242} \times 100 \% \\
& =3,14
\end{aligned}
$$

\section{Quick ratio}

$=\frac{\text { Kas }+ \text { Efek }+ \text { Piutang }}{\text { Hutang Lancar }} \times 100 \%$

23.076.640+124.904.045+17.680.168

790.752 .391

$=0.21$

\section{Working capital to total aset}

$=\frac{\text { Aktiva Lancar }- \text { Hutang Lncar }}{\text { Jumla } \text { h Aktiva }} \times 100 \%$

$=\frac{931.693 .351-790.752 .391}{931.693 .351}$ 
$=0.15$

\section{Solvability Ratio}

\section{Total Debt to total equity rasio}

$$
\begin{aligned}
= & \frac{\text { Hutang Lancar }+ \text { Hutang Jangka Panjang }}{\text { Modal Sendiri }} \\
& 100 \% \\
= & \frac{790.752 .391+95.909 .078}{140.940 .960} \times 100 \% \\
= & 6,29
\end{aligned}
$$

\section{Long Term to equity ratio}

$$
\begin{aligned}
& =\frac{\text { Hutang Jangka Panjang }}{\text { Modal Sendiri }} \times 100 \% \\
& =\frac{95.909 .078}{140.940 .960} \times 100 \% \\
& =0,68
\end{aligned}
$$

\section{Total Debt to Asset Ratio}

$$
\begin{aligned}
& =\frac{\text { Hutang Lancar }+ \text { Hutang Jangka Pendek }}{\text { Modal Sendiri }} \times 100 \\
& =\frac{790.752 .391+95.909 .078}{140.940 .960} \times 100 \% \\
& =6,29
\end{aligned}
$$

\section{BANK BNI}

\section{Likuidity Ratio}

\section{Current Ratio}

$$
\begin{aligned}
& =\frac{\text { Activa Lancar }}{\text { Hutang Lancar }} \times 100 \% \\
& =\frac{608.696 .288}{430.067 .066} \times 100 \% \\
& =1,41
\end{aligned}
$$

$$
=0,31
$$

\section{Quick ratio}

$$
\begin{aligned}
& =\frac{\text { Kas }+ \text { Efek }+ \text { Piutang }}{\text { Hutang Lancar }} \times 100 \% \\
& =\frac{58.178 .271}{430.067 .066} \\
& =0.14
\end{aligned}
$$

\section{Working capital to total aset}

$$
\begin{aligned}
& =\frac{\text { Aktiva Lancar }- \text { Hutang Lncar }}{\text { Jumla } \text { Aktiva }} \times 100 \% \\
& =\frac{608.696 .288-430.067 .066}{608.696 .288} \\
& =0.29
\end{aligned}
$$

\section{Solvability Ratio}

\section{Total Debt to total equity rasio}

$$
\begin{aligned}
= & \frac{\text { Hutang Lancar }+ \text { Hutang Jangka Panjang }}{\text { Modal Sendiri }} \quad \mathrm{X} \\
= & \frac{430.067 .066+44.437 .883}{77.469 .115} \times 100 \% \\
= & \frac{474.504 .949}{77.469 .115} \\
= & 6.13
\end{aligned}
$$

\section{Long Term to equity ratio}

$$
\begin{aligned}
& =\frac{\text { Hutang Jangka Panjang }}{\text { Modal Sendiri }} \times 100 \% \\
& =\frac{44.437 .883}{77.469 .115} \times 100 \% \\
& =\frac{474.504 .949}{77.469 .115} \\
& =0.57
\end{aligned}
$$

\section{Total Debt to Asset Ratio}

$$
\begin{aligned}
& =\frac{\text { Hutang Lancar }+ \text { Hutang Jangka Pendek }}{\text { Modal Sendiri }} \times 100 \\
& =\frac{430.067 .066+44.437 .883}{77.469 .115} \times 100 \%
\end{aligned}
$$




$$
\begin{aligned}
& =\frac{474.504 .949}{77.469 .115} \\
& =6.13
\end{aligned}
$$

\section{BANK MANDIRI}

\section{Likuidity Ratio}

\section{Current Ratio}

$$
\begin{aligned}
& =\frac{\text { Activa Lancar }}{\text { Hutang Lancar }} \times 100 \% \\
& =\frac{111.029 .455}{513.809 .696} \times 100 \% \\
& =0,21
\end{aligned}
$$

\section{Cash Ratio}

$$
\begin{aligned}
& =\frac{\text { Kas }+ \text { Efek }}{\text { Hutang Lancar }} \times 100 \% \\
& =\frac{16.808 .395+0}{513.809,696} \times 100 \% \\
& =0,03
\end{aligned}
$$

\section{Quick ratio}

$$
\begin{aligned}
& =\frac{\text { Kas }+ \text { Efek }+ \text { Piutang }}{\text { Hutang Lancar }} \times 100 \% \\
& =\frac{25.109 .124+16.516 .404+7.907 .499}{736.198 .705} \\
& =0.07
\end{aligned}
$$

\section{Working capital to total aset}

$$
\begin{aligned}
& =\frac{\text { Aktiva Lancar }- \text { Hutang Lncar }}{\text { Jumla } \text { h Aktiva }} \times 100 \% \\
& =\frac{910.063 .409-736.198 .705}{910.063 .409} \\
& =0.19
\end{aligned}
$$

\section{Solvability Ratio}

\section{Total Debt to total equity rasio}

$$
\begin{aligned}
= & \frac{\text { Hutang Lancar }+ \text { Hutang Jangka Panjang }}{\text { Modal Sendiri }} \\
& \times 100 \% \\
= & \frac{736.198 .705+41.244 .041}{119.491 .841} \times 100 \% \\
= & \frac{777.442 .746}{119.491 .841} \times 100 \% \\
= & 6.51
\end{aligned}
$$

\section{Long Term to equity ratio}

$$
\begin{aligned}
& =\frac{\text { Hutang Jangka Panjang }}{\text { Modal Sendiri }} \times 100 \% \\
& =\frac{41.244 .041}{119.491 .841} \times 100 \% \\
& =0.35
\end{aligned}
$$

\section{Total Debt to Asset Ratio}

$$
\begin{gathered}
=\frac{\text { Hutang Lancar }+ \text { Hutang Jangka Pendek }}{\text { Modal Sendiri }} \times 100 \\
=\frac{736.198 .705+41.244 .041}{119.491 .841} \times \\
\begin{array}{l}
100 \% \\
=
\end{array} \\
=6.51 .442 .746 \\
=619.491 .841
\end{gathered}
$$

\section{BANK CIMB NIAGA}

\section{Likuidity Ratio}

\section{Current Ratio}

$$
\begin{aligned}
& =\frac{\text { Activa Loncar }}{\text { Hitang Loncar }} \times 100 \% \\
& =\frac{286.026 .260}{180.081 .000} \times 100 \% \\
& =1,58
\end{aligned}
$$

\section{Cash Ratio}

$$
\begin{aligned}
& =\frac{\text { Kas }+ \text { Efek }}{\text { Hhtang Loncar }} \times 100 \% \\
& =\frac{281.717 .000+323.704 .000}{180.081 .000} \times 100 \% \\
& =3,36
\end{aligned}
$$

\section{Quick ratio}

$$
\begin{aligned}
& =\frac{\text { Kas }+ \text { Efek }+ \text { Puitang }}{\text { Hhtong Loncar }} \times 100 \% \\
& =\frac{281.717 .000+323.704 .000+2.979 .566}{180.081 .000} \times 100 \% \\
& =3,37
\end{aligned}
$$

Working capital to total aset

$$
\begin{aligned}
& =\frac{\text { Altiva Lonar }- \text { Hitang Lncar }}{\text { hmia h Altiva }} \times 100 \% \\
& =\frac{286.026 .260-180.081 .000}{205.070 .800} \times 100 \%
\end{aligned}
$$




$$
\begin{aligned}
& =\frac{100.945 .620}{205.070 .800} \times 100 \% \\
& =0,49
\end{aligned}
$$

\section{Solvability Ratio}

\section{Total Debt to total equity rasio}

$=\frac{\text { Hhtong Lancar } \quad \text { Hhtong Jongka Payjing }}{\text { Modal Sendiri }} \mathrm{x}$
$100 \%$
$=\frac{342.068 .400}{241.571 .728}$
$=1,41$

\section{Long Term to equity ratio}

$$
\begin{aligned}
& =\frac{\text { Hhtang Jangka Panjang }}{\text { Modal Sendiri }} \times 100 \% \\
& =\frac{180.081 .000}{532.136 .700} \times 100 \% \\
& =0.338 \times 100 \% \\
& =0,34
\end{aligned}
$$

\section{Total Debt to Asset Ratio}$$
=
$$

$\frac{\text { Hhtong Lonar +Hutong Jongka Pendek }}{\text { Modal Sendini }} \times 100$

$=\frac{161.987 .400}{532.136 .700} \times 100 \%$

$=0.304 \times 100 \%$

$=0,3$

\section{BANK BCA}

\section{Likuidity Ratio}

\section{Current Ratio}

$$
\begin{aligned}
& =\frac{\text { Activa Loncar }}{\text { Hutong Loncar }} \times 100 \% \\
& =\frac{604.049 .000}{796.000 .000} \times 100 \% \\
& =0,78
\end{aligned}
$$

\section{Cash Ratio}

$$
\begin{aligned}
& =\frac{\text { Kas }+ \text { Efek }}{\text { Hutang Lancar }} \times 100 \% \\
& =\frac{206.320 .000+112.135 .000}{796.000 .000} \times 100 \%
\end{aligned}
$$

$$
\begin{aligned}
& =\frac{318.455 .000}{796.000 .000} \times 100 \% \\
& =0,16
\end{aligned}
$$

\section{Quick ratio}

$$
\begin{aligned}
& =\frac{\text { Kas }+ \text { Ef ek }+ \text { Piutang }}{\text { Hutang Lancar }} \times 100 \% \\
& =\frac{206.320 .000+112.135 .000+0}{796.000 .000} \times 100 \% \\
& =\frac{318.455 .000}{796.000 .000} \times 100 \% \\
& =0.41
\end{aligned}
$$

\section{Working capital to total aset}

$$
\begin{aligned}
& =\frac{\text { Aktiva Lancar }- \text { Hutang Lncar }}{\text { Jumla h Aktiva }} \times 100 \% \\
& =\frac{604.000 .000-769.000 .000}{676.739 .000} \times 100 \% \\
& =\frac{-192.000 .000}{676.739 .000} \times 100 \% \\
& =-0,28
\end{aligned}
$$

\section{Solvability Ratio}

\section{Total Debt to total equity rasio}

$=\frac{\text { Hutang Lancar }+ \text { Hutang Jangka Panjang }}{\text { Modal Sendiri }} \times 100 \%$

$=\frac{112.715 .000}{676.739 .000}$

$=0,16$

\section{Long Term to equity ratio}

$$
\begin{aligned}
& =\frac{\text { Hutang Jangka Panjang }}{\text { Modal Sendiri }} \times 100 \% \\
& =\frac{0}{880.000 .0000} \times 100 \% \\
& =0 \times 100 \% \\
& =0
\end{aligned}
$$

\section{Total Debt to Asset Ratio}

$=$

$$
\begin{aligned}
& =\frac{769.000 .000-0}{880.000 .000} \times 100 \% \\
& =0 \times 100 \% \\
& =0,87
\end{aligned}
$$


Tabel 1. Hasil Analisa Kinerja Keuangan Perbankan di Indonesia Dilihat dari Likuiditas dan Solvabilitas

\begin{tabular}{|c|c|c|c|c|}
\hline \multirow{2}{*}{ Bank Name } & \multicolumn{2}{|r|}{ Nama Rasio } & \multirow{2}{*}{ Angka } & \multirow{2}{*}{ Kode } \\
\hline & Inti & Sub & & \\
\hline \multirow{7}{*}{ Bank BRI } & \multirow{4}{*}{$\begin{array}{c}\text { Rasio } \\
\text { Likuiditas }\end{array}$} & 1. Current Ratio & 0,96 & Likuid \\
\hline & & 2.Cash Ratio & 3,14 & Likuid \\
\hline & & 3.Quick Ratio & 0,21 & Likuid \\
\hline & & 4. Working Capital to Total Asset & 0,15 & Likuid \\
\hline & \multirow{3}{*}{$\begin{array}{c}\text { Rasio } \\
\text { Solvabilitas }\end{array}$} & 1. Total Debt to Total Equity Ratio & 6,29 & Solvabel \\
\hline & & 2. Long Term Debt to Equity Ratio & 0,68 & Solvabel \\
\hline & & 3. Total Debt to Total Ratio & 6,29 & Solvabel \\
\hline \multirow[t]{7}{*}{ Bank BNI } & \multirow{4}{*}{$\begin{array}{c}\text { Rasio } \\
\text { Likuiditas }\end{array}$} & 1. Current Ratio & 1.41 & Likuid \\
\hline & & 2.Cash Ratio & 0,31 & Likuid \\
\hline & & 3.Quick Ratio & 0,14 & Likuid \\
\hline & & 4. Working Capital to Total Asset & 0,29 & Likuid \\
\hline & \multirow{3}{*}{$\begin{array}{c}\text { Rasio } \\
\text { Solvabilitas }\end{array}$} & 1. Total Debt to Total Equity Ratio & 6,13 & Solvabel \\
\hline & & 2. Long Term Debt to Equity Ratio & 0,57 & Solvabel \\
\hline & & 3. Total Debt to Total Ratio & 6,13 & Solvabel \\
\hline \multirow[t]{7}{*}{ Bank Mandiri } & \multirow{4}{*}{$\begin{array}{c}\text { Rasio } \\
\text { Likuiditas }\end{array}$} & 1. Current Ratio & 0,21 & Likuid \\
\hline & & 2.Cash Ratio & 0,03 & Likuid \\
\hline & & 3.Quick Ratio & 0,19 & Likuid \\
\hline & & 4. Working Capital to Total Asset & 1.24 & Likuid \\
\hline & \multirow{3}{*}{$\begin{array}{c}\text { Rasio } \\
\text { Solvabilitas }\end{array}$} & 1. Total Debt to Total Equity Ratio & 6,51 & Solvabel \\
\hline & & 2. Long Term Debt to Equity Ratio & 0,34 & Solvabel \\
\hline & & 3. Total Debt to Total Ratio & 6,51 & Solvabel \\
\hline \multirow{7}{*}{ Bank BCA } & \multirow{4}{*}{$\begin{array}{c}\text { Rasio } \\
\text { Likuiditas }\end{array}$} & 1. Current Ratio & 0,78 & Likuid \\
\hline & & 2.Cash Ratio & 0,16 & Likuid \\
\hline & & 3.Quick Ratio & 0,41 & Likuid \\
\hline & & 4. Working Capital to Total Asset & $-0,28$ & $\begin{array}{c}\text { Tidak } \\
\text { Likuid }\end{array}$ \\
\hline & \multirow{3}{*}{$\begin{array}{c}\text { Rasio } \\
\text { Solvabilitas }\end{array}$} & 1. Total Debt to Total Equity Ratio & 0,16 & Solvabel \\
\hline & & 2. Long Term Debt to Equity Ratio & 0,87 & Solvabel \\
\hline & & 3. Total Debt to Total Ratio & 0 & Solvabel \\
\hline \multirow{7}{*}{$\begin{array}{l}\text { Bank CIMB } \\
\text { NIAGA }\end{array}$} & \multirow{4}{*}{$\begin{array}{c}\text { Rasio } \\
\text { Likuiditas }\end{array}$} & 1. Current Ratio & 1,58 & Likuid \\
\hline & & 2.Cash Ratio & 3,36 & Likuid \\
\hline & & 3.Quick Ratio & 3,37 & Likuid \\
\hline & & 4. Working Capital to Total Asset & 0,49 & Likuid \\
\hline & \multirow{3}{*}{$\begin{array}{c}\text { Rasio } \\
\text { Solvabilitas }\end{array}$} & 1. Total Debt to Total Equity Ratio & 1,41 & Solvabel \\
\hline & & 2. Long Term Debt to Equity Ratio & 0,34 & Solvabel \\
\hline & & 3. Total Debt to Total Ratio & 0,3 & Solvabel \\
\hline
\end{tabular}




\section{PEMBAHASAN}

\section{Rasio Likuiditas}

Pada umumnya dapat dikatakan kinerja keuangan yang likuid karena jumlah aktiva masih besar jika dibandingkan dengan hutang bank sehingga proses operaasional perbankan dapat berlangsung dengan cukup baik.

Likuiditas yang dicapai oleh Bank BRI dari empat rasio yang ada cukup likuid walaupun tidak terlalu besar berkisar antara 0,15 hingga 0,96, dapat diartikan bahwa jumlah aktiva lancar, kas, efek dan piutang lebih besar dari pada hutang lancar seperti yang ditunjukkan pada tabel, besar rasio kas bahkan dapat mencapai 3,14 berarti kas dan efeknya lebih besar daripada hutang lancar

Pada Bank BNI menunjukkan hal yang sama dimana mayoritas jumlah aktiva lancar, kas, efek dan piutang lebih besar dari pada hutang lancar berkisar 0,14 hingga 0,31, bahkan pada rasio kas lmencapai 1,41 dimana aktiva lebih besar dari hutang lancar

Pencapaian pada Bank Mandiri juga tidak berbeda jauh, walau terkategori bank besar karena merupakan hasil "merger" atau bersatunya beberapa bank menjadi satu, yang mendukung aktivitas perbankan secara lebih berkelanjutan, hal ini menyebabkan pencapaian berkisar 0,03 hingga 0,21

Untuk Bank BCA secara umum masih bisa dikategorikan likuid dikarenakan . kas, efek dan piutang lebih besar daripada hutang lancar walaupun tidak terlalu besar, namun pada rasio modal kerja terhadap total aktiva, jumlah aktiva lancar lebih kecil daripada hutang lancar sebesar $-0,28$ sehingga pada kondisi ini likuiditasnya tidak tercapai atau tidak likuid

Sebagai bank yang belum lama berdiri, CIMB Niaga masih memiliki keunggulan-keunggulan, seperti jumlah aktiva lancar, kas, efek dan piutang lebih besar dari pada hutang lancar, sehingga posisi likuiditas yang dapat dicapainya antara 0,49 hingga 3,37 sehingga sangat baik untuk menjalankan operasional perusahaan hingga beberapa tahun ke depan

\section{Rasio Solvabilitas}

Rasio Solvabilitas yang dicapai dari kelima bank menunjukkan bahwa solvabel, dikarenakan dari setiap rupiah modal sendiri yang dimiliki masih dapat dijadilan jaminan untuk keseluruhan hutang jangka panjang 
Solvabilitas yang dicapai oleh Bank BRI dari tiga rasio yang ada cukup solvabel dimana antara total hutang yang dmiliki berikut utang jangka panjangnya pada kenyataannya masih cukup tinggi 6,29 namun masih dapat dibiayai oleh total asset dan modal sendiri yang ada, baiknya utang lancarnya lebih besar dari utang jangka panjang sehingga masih bisa dibiayai juga oleh modal sendiri 0,68

Pada Bank BNI tidak jauh berbeda dimana antara total hutang yang dmiliki berikut utang jangka panjangnya pada kenyataannya masih cukup tinggi 6,13 namun masih dapat dibiayai oleh total asset dan modal sendiri yang ada, baiknya utang lancarnya lebih besar dari utang jangka panjang sehingga masih bisa dibiayai juga oleh modal sendiri 0,57

Berikut Pencapaian pada Bank Mandiri juga solvabel dimana antara total hutang yang dmiliki berikut utang jangka panjangnya pada kenyataannya masih cukup tinggi 6,51 namun masih dapat dibiayai oleh total asset dan modal sendiri yang ada, baiknya utang lancarnya lebih besar dari utang jangka panjang sehingga masih bisa dibiayai juga oleh modal sendiri 0,34
Dari ketiga bank sebelumnya, Bank BCA lebih baik tingkat solvabilitas dimana antara total hutang yang dmiliki dan total asset 0,16 berikut hanya ada utang lancarnya saja dan tidak ada utang jangka panjang sehingga 0,87 , baiknya karena tidak ada utang jangka panjang sehingga masih bisa ddapat dibiayai juga oleh modal sendiri 0

Sebagai bank yang belum lama berdiri, CIMB Niaga masih memiliki keunggulan-keunggulan, seperti untuk total hutang dimana belum terdapat hutang ang jangka panjang sehingga untuk modal yang dimiliki masih dapat membiayai perusahaan untuk melakukan pembayaran atas total hutangnya sebesar 1,41, sedangkan modal sendiri pun masih dapat dilakukan untuk pembiayaan atas hutang lancarnya dikarenakan belum adanya hutang jangka panjang sebesar 0,34, kemudian rasio hutang atas kesulurahan rasio total dikarenakan belum adanya hutang jangka panjang hingga modal sendiri yang dimiliki tidak perlu dikerluarkan sehingga 0

\section{KESIMPULAN}

Berdasarkan pembahasan sebelumnya dapat disimpulkan bahwa 
Kinerja Keuangan perbankan di Indonesia Likuid dan Solvabel, sebagai bank besar yang berkembang sangat pesat, mereka memiliki asset dan modal sendiri yang masih kuat sehingga dapat membiayai pelaksanaan operasional perbankan di perusahaan mereka masing-masing, namun begitu mereka tetap harus memperhatikan persediaan dana dan modal yang mereka miliki dengan membuat suatu program unggulan jasa perbankan yang menarik nasabah dan investor untuk menanamkan modal berikut disertai dengan pelayanan kepada nasabah yang ditamakan sehingga mereka merasa nyaman dan aman melakukan transaksi di kelima bank seperti yang telah disebutkan sebelumnya

\section{SARAN}

Peningkatan program unggulan jasa perbankan yang menarik nasabah, seperti: melakukan pembuatan rekening bagi segala usia, di desa dan kota, pemberian informasi yang jelas atas keunggulan dan laporan keuangan masing-masing perbankan kepada investor untuk menanamkan modal berikut disertai dengan pelayanan kepada nasabah yang diutamakan sehingga mereka merasa nyaman dan aman dalam melakukan transaksi perbankan di kelima bank seperti yang telah disebutkan

\section{DAFTAR PUSTAKA}

Arikunto, Suharsimi. 2010. Prosedur Penelitian suatu Pendekatan Praktik. Jakarta: Rineka Cipta . 2012. Prosedur Penelitian suatu Pendekatan Praktik. Jakarta: Rineka Cipta . 2013. Prosedur Penelitian suatu Pendekatan Praktik. Jakarta: Rineka Cipta

Dendawijaya, Lukman. 2009. Manajemen Perbankan, Ghalia Indonesia, Jakarta.

Djamarah,Bahri,Syaiful . 2010. Strategi Pembelajaran Jakarta: Bumi Aksara.

Fakultas Keguruan dan Ilmu Pendidikan. 2015. Pedoman Penulisan Skripsi. Palembang: Universitas PGRI.

Hamdani, 2011. Strategi Belajar Mengajar. Bandung: Pustaka Setia

Harahap, Sofyan Syafri. 2009. Analisis Kritis Atas Laporan Keuangan, Jakarta : PT RajaGrafindo

Jumingan, 2011. Analisis Laporan Keuangan. Jakarta : Bumi Aksara

Kasmir. 2002. Bank dan Lembaga Keuangan Lainnya, PT. Raja Grafindo persada, Jakarta.

Kasmir. 2012. Analisis Laporan Keuangan, Edisi keenam, PT. Raja Grafindo persada, Jakarta.

Kuncoro, Mudrajad dan Suhardjono, 2011. Manajemen Perbankan teori dan Aplikasi, BPFE, Yogyakarta.

LPPKMK Universitas PGRI. 2012. Pedoman Penulisan Penelitian Dosen._Palembang : Puslit Universitas PGRI Palembang 
Munawir, Drs. S. Analisa Laporan Keuangan, Yogyakarta : Liberty

Purwanto, Ngalim. 2013. Prinsipprinsip dan Teknik Evaluasi Pengajaran. Bandung: PT. Remaja Rosdakarya

Sawir, Agnes. 2005. Analisis Kinerja Keuangan dan Perencanaan Keuangan Perusahaan. PT Gramedia Pustaka, Jakarta.

Thomas, Suyatno. 2007. Kelembagaan Perbankan, PT. Gramedia Pustaka Utama, Jakarta.

Undang-Undang Republik Indonesia No. 10 Tahun 1998 Tentang Perubahan Undang-Undang No. 7 Tahun 1992 Tentang Perbankan. 